\title{
ROLE MODEL PENDEKATAN EDUKATIF HEALTH PROMOTION TERHADAP PENURUNAN STIGMA MASYARAKAT TENTANG PENYAKIT KUSTA
}

Role Model for Educative Approach of Health Promotion to The Decreasing Stigma of Leprosy Disease

\author{
Rifa'i ${ }^{1}$, Novi Kusrini' ${ }^{2}$, Supriliyah Praningsih ${ }^{1}$ \\ 1Sekolah Tinggi llmu Kesehatan Pemkab Jombang \\ 2Dinas Kesehatan Kabupaten Jombang \\ *) ners.rifai@gmail.com
}

\begin{abstract}
Leprosy or morbushansen is a chronic infectious disease which is caused by mycobacterium leprae that attacks the peripheral nerves, skin and other body tissues. It can cause very complex problems, both physical, social and economic problems, which have severe consequences, namely deformity or disability and changes in body shape, low self-esteem and shame. the existence of negative stigma from society, illness due to curse, disgusting and incurable feared by the family and community, the community shunned and felt ostracized by the community. The design of study is Pre-experimental research design, One group pre - post test design. The population is 35 community members, community leaders, religion, adolescents, program of family welfare in village, the village officials. sample of 35 people used total sampling, Independent Variable was Health Promotion of leprosy, while dependent variable was reduction in Community Stigma About Leprosy, statistical test used Wilcoxon sign rank test. The results of study in the pre-test community stigma about leprosy were mostly negative at 24 respondents (68.8\%) and posttest were mostly positive stigmatized at 21 respondents (60\%). It can be concluded that there is an influence of role models for educative approach of health promotion to decreased community stigma of leprosy in Menganto Village, Mojowarno, Jombang.
\end{abstract}

Keywords : role model, health promotion educative, stigma of Leprosy

\begin{abstract}
ABSTRAK
Kusta (lepra) atau morbus hansen merupakan penyakit menular yang menahun disebabkan oleh mycobacterium leprae yang menyerang syaraf tepi, kulit dan jaringan tubuh lainnya. Penyakit yang menimbulkan masalah yang sangat kompleks, baik fisik maupun masalah sosial dan ekonomi, yang berdampak cukup parah, yaitu deformitas atau kecacatan dan perubahan bentuk tubuh, rendah diri dan malu. adanya stigma negatif dari masyarakat, penyakit akibat kutukan, menjjijkan dan tidak dapat di sembuhkan ditakuti keluarga dan masyarakat, masyarakat menjauhi dan merasa terkucilkan oleh masyarakat. Desain penelitian dengan Pre-Exsperimental, pendekatan One group pre test post test design. Populasi adalah 35 orang warga masyarakat, tokoh masyarakat, agama, remaja, PKK perangkat desa, BPD PKK. sampel 35 orang, total sampling, Variable Independen Pemberian Pendidikan kesehatan Health Promotion tentang penyakit kusta, variable dependen penurunan Stigma Masyarakat Tentang Penyakit Kusta, uji statistik wilcoxon sign rank test. Hasil penelitian pada pre test menunjukkan stigma masyarakat tentang penyakit kusta sebagian besar negatif yaitu sebesar 24 responden $(68,8 \%)$ dan postest sebagian besar berstigma positif sebanyak 21 responden (60\%). Kesimpulan penelitian adalah ada pengaruh role model pendekatan edukatif health promotion terhadap penurunan stigma masyarakat tentang penyakit kusta di Desa Menganto Kecamatan Mojowarno Kabupaten Jombang.
\end{abstract}

Kata kunci : role model, edukatif health promotion, stigma penyakit Kusta

\section{PENDAHULUAN}

Kusta (lepra) atau morbus hansen merupakan penyakit menular yang menahun dan disebabkan oleh kuman kusta (mycobacterium leprae) yang menyerang syaraf tepi, kulit dan jaringan tubuh lainnya. Penyakit yang menimbulkan masalah yang sangat kompleks, tidak hanya dari segi medis (kecacatan fisik), tetapi juga meluas sampai masalah sosial dan ekonomi, stigma negatif dari masyarakat, yang menakutkan. Yang berdampak cukup parah, yaitu deformitas atau kecacatan dan perubahan bentuk tubuh, penderita merasa rendah diri dan malu. Anggapan bahwa penyakit kusta di sebabkan karena kutukan, penyakit menular yang menjijikan dan tidak dapat di sembuhkan penyakit kusta merupakan penyakit yang ditakuti masyarakat bahkan keluarga penyakit yang ditakuti oleh keluarga dan masyarakat, masyarakat menjauhi dan merasa terkucilkan oleh masyarakat, (Mongi,2012). 
Laporan regional WHO tahun 2000, Indonesia sebagai peringkat keempat dunia setelah India, Brazil dan Nepal, tahun 2011 indonesia telah menempati peringkat ketiga di dunia setelah India dan Brazil. Data Depkes tahun 2012 dilaporkan ada 18.994 kasus kusta baru di Indonesia dan 2.131 penderita $(11,2 \%)$ diantaranya sudah cacat pada tingkat 2, yaitu cacat kelihatan.

Melihat sejarah, penyakit kusta merupakan penyakit yang ditakuti oleh keluarga dan masyarakat. Saat itu telah terjadi pengasingan secara spontan, penderita merasa rendah diri dan malu. Masyarakat menjauhi penderita kusta karena kurangnya pengetahuan atau pengertian juga kepercayaan yang keliru terhadap penyakit kusta. Masyarakat menganggap penyakit kusta disebabkan oleh kutukan dan guna-guna, proses inilah yang membuat para penderita terkucil dari masyarakat, dianggap menakutkan dan harus dijauhi, adanya stigma dan persepsi yang keliru dari msyarakat (Soedarjatmi, 2009). Penderita menjadi tidak mampu melaksanakan fungsi sosial dan normal serta kehilangan status sosial secara progresif, terisolasi dari masyarakat, keluarga dan teman-temannya (Munir, 2001). cenderung hidup menyendiri dan mengurangi kegiatan sosial di lingkungan sekitar (Leprosy Review, 2005). Penderita cenderung merasa malu dan ketakutan untuk bertemu dengan orang lain. Hal itu akan membuat penderita menjadi tuna sosial. Penderita pun menjadi tidak mampu melaksanakan fungsi sosial secara normal serta kehilangan status sosial secara progresif. stigma menyebabkan penderita seringkali tidak dapat menerima kenyataan bahwa ia menderita kusta. Akibatnya akan ada perubahan mendasar pada kepribadian dan tingkah lakunya.

Dukungan spiritual dan sosial dari keluarga dan masyarakat, adanya interaksi anggota keluarga dalam bentuk harapan (Priastana, Haryanto, Suprajitno, 2018). Hal ini meyakinkan anggotanya keluarga serta masyarakat untuk menciptakan stigma yang positif dan dukungan sosial masyarakat demi kesembuhan penderita kusta.

\section{METODE}

\section{Desain, tempat dan waktu}

Desain penelitian yang digunakan adalah pra exsperimental, peneliti ingin menganalisis pengaruh Role Model Pendekatan Edukatif Health Promotion Terhadap Penurunan Stigma Masyarakat Tentang Penyakit Kusta Di Desa Mayangan Kecamatan Jogoroto Kabupaten Jombang, dengan pendekatan one group pra test - post test design, yang melibatkan satu kelompok subjek. kelompok subjek diobservasi sebelum dilakukan intervensi (pre test), kemudian dilakukan intervensi (Health
Promotion) dan diobservasi lagi setelah intervensi (Post test).

\section{Jumlah dan cara pengambilan subjek}

Populasi dalam penelitian ini warga Desa Menganto Kecamatan Mojowarno Kabupaten Jombang 35 orang, dengan sampel 35 responden dengan total sampling yaitu 35 orang. Penelitian ini dilakukan setelah mendapatkan izin penelitian dari kepala dinas kesehatan kabupaten Jombang, kepala pukesmas Menganto, dan kepala desa Menganto, Peneliti mengumpulkan responden di balai desa Menganto dan. peneliti menjelaskan maksud dan tujuan serta manfaat penelitian kepada responden serta memohon izin kepada seluruh responden untuk dapatnya memberikan persetujuan dan menandatangani persetujuan (Informed consent). Selanjutnya peneliti membagikan questioner untuk pre-test dan lakukan health promotion dan seminggu berikutnya dilakukan post-test menganalisis hasil penelitiannya. Analisis data dengan menggunakan uji statistik wilcoxon sign rank test skala ordinal.

HASIL

Tabel 1

Karakteristik Responden

\begin{tabular}{lcc}
\hline Karakteristik Sampel & \multicolumn{2}{c}{ Kelompok 1 } \\
\cline { 2 - 3 } & $\mathbf{n}$ & $\%$ \\
\hline Jenis Kelamin & & \\
Laki-laki & 0 & 0 \\
$\quad$ Perempuan & 35 & 100 \\
\hline Umur & & \\
$26-35$ tahun & 4 & 11,4 \\
$36-45$ tahun & 18 & 51,4 \\
$46-55$ tahun & 11 & 31,4 \\
$56-65$ tahun & 2 & 5,7 \\
\hline Pendidikan & & \\
SD & 10 & 28,6 \\
SLTP & 21 & 60 \\
SLTA & 1 & 2,9 \\
& & \\
\hline Pekerjaan & & \\
Wiraswasta & 10 & 28,6 \\
Tidak bekerja & 21 & 60 \\
Militer & 1 & 2,9 \\
Petani & 1 & 2,9 \\
Lain-lain & 2 & 5,7 \\
\hline
\end{tabular}

Berdasarkan tabel 1 dapat dijelaskan bahwa demografi masyarakat dilaksanakan didesa mayangan Kecamatan Mayangan Jogoroto kabupaten Jombang, secara keseluruhan masyarakat berjenis kelamin perempuan sebanyak 35 responden $(100 \%)$, umur responden sebagian 
besar 36 - 45 tahun sebanyak 18 responden $(51,4)$, pendidikan sebagian besar 21 responden $(60 \%)$ dan pekerjaan sebagian besar tidak bekerja sebanyak 21 responden $(60 \%)$.

Tabel 2

Hasil Analisis Wilcoxon Sign Rank Test

\begin{tabular}{lccccc}
$\begin{array}{l}\text { Health } \\
\text { Rromotion }\end{array}$ & Pretest & \multicolumn{2}{c}{ Postest } \\
$\begin{array}{l}\text { Stigma } \\
\text { Masyarakat }\end{array}$ & $\mathrm{n}$ & $\%$ & $\mathrm{n}$ & $\%$ & $p$ \\
\hline Positif & 11 & 31,4 & 21 & 60 & \\
Negatif & 24 & 68,6 & 14 & 40 & 0.002 \\
Total & 35 & 100 & 35 & 100 & \\
\hline
\end{tabular}

Berdasarkan tabel 2 dijelaskan tentang pengaruh role model pendekatan edukatif health promotion terhadap penurunan stigma masyarakat tentang penyakit kusta di Desa Menganto Kecamatan Mojowarno Kabupaten Jombang, stigma Masyarakat Tentang Penyakit Kusta sebelum (pretest) health promotion sebagian besar negatif yaitu sebanyak 24 responden $(68,6 \%)$, sedangkan stigma Masyarakat Tentang Penyakit Kusta sesudah (postest) Health Promotion sebagian besar positif yaitu sebanyak 21 responden $(60 \%)$. Berdasarkan analisis wilcoxon sign rank test didapatkan nilai $p=$ $0,002<a(0,05)$ disimpulkan bahwa ada pengaruh role model pendekatan edukatif health promotion terhadap penurunan stigma masyarakat tentang penyakit kusta di Desa Menganto Kecamatan Mojowarno Kabupaten Jombang.

\section{PEMBAHASAN}

\section{Stigma Masyarakat Tentang Penyakit Kusta}

Stigma Masyarakat Tentang Penyakit Kusta sebelum Health Promotion sebagian besar negatif yaitu sebanyak 24 responden $(68,6 \%)$ dan positif sebesar 11 responden $(31,4 \%)$, sedangkan sesudah (postest) Health Promotion sebagian besar positif yaitu sebanyak 21 responden $(60 \%)$ dan negatif sebesar 14 responden (40\%).

Penyakit kusta merupakan penyakit yang ditakuti oleh keluarga dan masyarakat. Saat itu telah terjadi pengasingan secara spontan, penderita merasa rendah diri dan malu. Masyarakat menjauhi penderita kusta karena kurangnya pengetahuan atau pengertian juga kepercayaan yang keliru terhadap penyakit kusta. Masyarakat menganggap penyakit kusta disebabkan oleh kutukan dan guna-guna, proses inilah yang membuat para penderita terkucil dari masyarakat, dianggap menakutkan dan harus dijauhi, adanya stigma dan persepsi yang keliru dari msyarakat (Soedarjatmi, 2009). Penderita menjadi tidak mampu melaksanakan fungsi sosial dan normal serta kehilangan status sosial secara progresif, terisolasi dari masyarakat, keluarga dan temantemannya (Munir, 2001). Cenderung hidup menyendiri dan mengurangi kegiatan sosial di lingkungan sekitar (Leprosy Review, 2005). Penderita cenderung merasa malu dan ketakutan untuk bertemu dengan orang lain. Hal itu akan membuat penderita menjadi tuna sosial. Penderita pun menjadi tidak mampu melaksanakan fungsi sosial secara normal serta kehilangan status sosial secara progresif. stigma menyebabkan penderita seringkali tidak dapat menerima kenyataan bahwa ia menderita kusta. Akibatnya akan ada perubahan mendasar pada kepribadian dan tingkah lakunya.

Stigma masyarakat sangat mempengaruhi kehidupan pasien kusta baik psikologis maupun mental karena mereka merasa tidak diterima dan dikucilkan oleh masyarakat. Banyak pasien kusta malu untuk bersosialisasi maupun bergaul dengan lingkungan sekitar karena kecacatan yang ditimbulkan dari komplikasi penyakit kusta itu sendiri.Penderita kusta lebih banyak berdiam diri dan bersembunyi dirumah karena perlakuan diskriminasi yang mereka terima dari masyarakat. Dengan hanya berdiam diri dirumah membuat mereka tidak memperoleh pengobatan yang maksimal sehingga kondisi menjadi semakin parah sampai pada terjadinya cacat yang permanen. Kondisi inilah yang membuat proses penularan penyakit semakin cepat sehingga prevalensi penyakit kusta semakin meningkat setiaptahunnya

Pengaruh Role Model Pendekatan Edukatif Health
Promotion Terhadap Penurunan Stigma
Masyarakat Tentang Penyakit Kusta DI Desa
Menganto Kecamatan Mojowarno Kabupaten
Jombang
Pengaruh role model pendekatan edukatif health promotion terhadap penurunan stigma masyarakat tentang penyakit kusta di Desa Menganto Kecamatan Mojowarno Kabupaten Jombang, stigma Masyarakat Tentang Penyakit Kusta sebelum (pretest) health promotion sebagian besar negatif yaitu sebanyak 24 responden $(68,6 \%)$, sedangkan stigma Masyarakat Tentang Penyakit Kusta sesudah (postest) Health Promotion sebagian besar positif yaitu sebanyak 21 responden $(60 \%)$. berdasarkan analisis wilcoxon sign rank test di dapatkan nilai $p=0,002<a(0,05)$ disimpulkan bahwa ada pengaruh role model pendekatan edukatif health promotion terhadap penurunan stigma masyarakat tentang penyakit kusta di Desa Menganto Kecamatan Mojowarno Kabupaten Jombang

Menurut Kementrian Kesehatan Republik Indonesia (2012), menyebutkan bahwa ada 3 strategi 
yang dapat dilakukan untuk menghentikan stigma di masyarakat, yaitu protes, pendidikan kesehatan, dan kontak. Protes untuk enghilangkan penyataan negatif masyarakat, media, dan iklan. Pendidikan kesehatan dapat memberikan informasi yang lengkap dan jelas mengenai penyakit sehingga orang yang erpengetahuan lebih bisa bijak dalam berhubungan dengan orang yang memiliki penyakit dan tidak akan mendiskriminasinya. Kontak, maksudnya adalah orang yang memiliki penyakit dapat berkumpul dengan orang yang memiliki penyakit yang sama sehingga dapat meningkatkan arga dirinya dan semakin percaya diri. Adanya perkumpulan khusus juga dapat mengurangi kecemasan seseorang dan bisa saling mengungkapkan perasaannya selama didiagnosa enyakit (Kementrian Kesehatan Republik Indonesia, 2012).

Promosi kesehatan dapat memberikan informasi yang lengkap dan jelas mengenai penyakit sehingga orang yang berpengetahuan lebih bisa bijak dalam berhubungan dengan orang yang memiliki penyakit dan tidak akan mendiskriminasinya. Kontak, maksudnya adalah orang yang memiliki penyakit dapat berkumpul dengan orang yang memiliki penyakit yang sama sehingga dapat meningkatkan harga dirinya dan semakin percaya diri. Adanya perkumpulan khusus juga dapat mengurangi kecemasan seseorang dan bisa saling mengungkapkan perasaannya selama didiagnosa penyakit

Kusta merupakan salah satu penyakit menular yang menimbulkan masalah yang sangat kompleks. Masalah yang dimaksud bukan hanya dari segi medis tetapi meluas hingga masalah sosial, ekonomi, dan budaya karena Kusta sampai saat ini masih merupakan stigma di masyarakat, keluarga, termasuk sebagian petugas kesehatan. Hal ini disebabkan masih kurangnya pengetahuan atau pengertian, kepercayaan yang keliru terhadap Kusta dan disabilitas yang ditimbulkannya.

Penyuluhan mengenai Kusta dilakukan secara komprehensif yang meliputi segala aspek baik medis maupun non medis. Penyuluhan bertujuan agar Penderita Kusta dan keluarga dapat mengenali tanda dan gejala disabilitas, berobat dengan tuntas, melakukan perawatan diri, serta menghilangkan stigma dan diskriminasi. Penyuluhan mengenai Kusta dilakukan oleh tenaga kesehatan dan masyarakat terlatih termasuk OYPMK. Sasaran penyuluhan adalah Penderita Kusta, keluarga, dan masyarakat.

Promosi kesehatan dilakukan dengan berbagai upaya kepada masyarakat sehingga mereka mau dan mampu meningkatkan dan memelihara kesehatan mereka sendiri. Promosi kesehatan dilakukan melalui sinergisitas Pemerintah Pusat dan Pemerintah Daerah, organisasi kemasyarakatan, swasta/dunia usaha, dan masyarakat yang telah diberikan pengetahuan mengenai Kusta antara lain kader, tokoh masyarakat, serta Orang yang Pernah Mengalami Kusta (OYPMK). Sasaran promosi kesehatan dalam kegiatan Penanggulangan Kusta yaitu Penderita Kusta, keluarga, masyarakat termasuk tokoh masyarakat, tokoh agama, tokoh adat, tokoh publik,organisasi kemasyarakatan, dan kader, tenaga kesehatan, penentu kebijakan dan pemangku kepentingan.

Surveilans Kusta dalam kegiatan Penanggulangan Kusta dalam upaya menurunkan stigma adalah sebagai berikut:

1. Pemeriksaan kontak

2. Rapid Village Survey, intensifikasi penemuan Penderita Kusta tingkat kabupaten/kota, dan pemeriksaan anak sekolah Rapid Village Survey (RVS)

3. Kegiatan partisipasi masyarakat dalam Penanggulangan Kusta melalui Desa Sahabat Kusta, Cinta Keluarga, Kelompok Sobat Kusta yang berbasis masyarakat.

4. Diseminasi informasi juga ditujukan kepada seluruh stakeholder yang terkait, yaitu jajaran kesehatan, LSM, profesi, perguruan tinggi, dan masyarakat.

5. Kemoprofilaksis Kusta adalah pemberian obat yang ditujukan untuk pencegahan Kusta

\section{KESIMPULAN}

Dapat disimpulkan bahwa ada pengaruh role model pendekatan edukatif health promotion terhadap penurunan stigma masyarakat tentang penyakit kusta di Desa Menganto Kecamatan Mojowarno Kabupaten Jombang.

\section{DAFTAR PUSTAKA}

Daniel, E. (2006). Clinical science: Incidence of ocular morbidity among multibacillary leprosy patients during a 2 year course of multidrug therapy. $\mathrm{Br} \mathrm{J}$ Ophthalmol, 90: 568-573.

Depkes RI. (2005). Buku Pedoman Pemberantasan Penyakit Kusta. Jakarta: Depkes RI

Dwi, S., Sri N., Isnani, Z. A. (2012). Faktor Risiko Multidrug Resistant Tuberculosis (MDR-TB). Jurnal Kemas, 8 (1): 
60-66.

Johnson, C. M. (2007). Cutting Edge: A Common Polymorphism Impairs Cell Surface Trafficking and Functional Responses of TLR1 but Protects against Leprosy. The Journal of Immunology, 178(12): 7520-7524.

Ligia, R. S. K. (2006). Socioeconomic, environmental, and behavioural risk factors for leprosy in North-east Brazil: results of a casecontrol study. Int. J. Epidemiol., 35(4): 994-1000.

Moet, F. J. (2006). Physical Distance, Genetic Relationship, Age, and Leprosy Classification Are Independent Risk Factors for Leprosy in Contacts of Patients with Leprosy. J Infect Dis., 193(3): 346-353.

Priastana, I. K. A., Haryanto, J., \& Suprajitno, S. (2018). Peran Dukungan Sosial Keluarga terhadap Berduka Kronis pada Lansia yang Mengalami Kehilangan Pasangan dalam Budaya Pakurenan. Indonesian Journal of Health Research, 1(1), 20-26. https://doi.org/10.32805/jhr.2018.1.1.8

Solomon, A. W. (2005). Clinical science: Prevalence and causes of blindness and low vision in leprosy villages of north eastern Nigeria. Br J Ophthalmol, 89: 417-419.

Spencer, J. S. (2005). Identification of Specific Proteins and Peptides in Mycobacterium leprae Suitable for the Selective Diagnosis of Leprosy. The Journal of Immunology, 175(12): 7930-7938.

Suprapti. (2001). Faktor-Faktor yang Berkaitan dengan Kejadian Kusta di Kabupaten Blora Tahun 2000. FKM UNDIP, Semarang.

Vinay, K. (2009). Human Immunodeficiency Virus and Leprosy Coinfection in Pune, India. J. Clin. Microbiol., 47(9): 2998-2999.

Weng, X. (2007). Identification and Distribution of Mycobacterium leprae Genotypes in a Region of High Leprosy Prevalence in China: a 3-Year Molecular Epidemiological Study. J. Clin. Microbiol., 45(6): 1728-1734. 